\title{
Anti-Sickle Cell Anemia and Bacterial Inhibitory Effects of Uvariodendron molundense (Diels) R.E.Fr. (Annonaceae) from Ubangi River Basin, DR Congo
}

\author{
Koto-Te-Nyiwa Ngbolua ${ }^{1,2,3 *}$, Dorotheé D. Tshilanda4, Djolu R. Djoza ${ }^{3}$, Clarisse M. Falanga1, \\ Masengo C. Ashande ${ }^{3}$, Damien S. T. Tshibangu${ }^{4}$, Jeff B. Iteku', Virima Mudogo ${ }^{4}$, Pius T. Mpiana ${ }^{4}$ \\ ${ }^{1}$ Département de Biologie, Faculté des Sciences, Université de Kinshasa, Kinshasa, République Démocratique du Congo \\ ${ }^{2}$ Institut Supérieur Pédagogique d'Abumombazi, Abumombazi, République Démocratique du Congo \\ ${ }^{3}$ Département des Sciences de l'Environnement, Faculté des Sciences, Université de Gbadolite, Gbadolite, \\ République Démocratique du Congo \\ ${ }^{4}$ Département de Chimie, Faculté des Sciences, Université de Kinshasa, Kinshasa, République Démocratique du Congo \\ Email: ^jpngbolua@unikin.ac.cd
}

How to cite this paper: Ngbolua, K.-T.-N., Tshilanda, D.D., Djoza, D.R., Falanga, C.M., Ashande, M.C., Tshibangu, D.S.T., Iteku, J.B., Mudogo, V. and Mpiana, P.T. (2017) Anti-Sickle Cell Anemia and Bacterial Inhibitory Effects of Uvariodendron molundense (Diels) R.E.Fr. (Annonaceae) from Ubangi River Basin, DR Congo. Journal of Biosciences and Medicines, 5, 71-84. https://doi.org/10.4236/jbm.2017.53008

Received: January 7, 2017

Accepted: March 19, 2017

Published: March 22, 2017

Copyright @ 2017 by authors and Scientific Research Publishing Inc. This work is licensed under the Creative Commons Attribution International License (CC BY 4.0).

http://creativecommons.org/licenses/by/4.0/ (c) (i) Open Access

\begin{abstract}
The present study was carried out with the aim of evaluating the chemical composition and bioactivity of Uvariodendron molundense against Sickle cell disease and associated pathogenic bacteria agents. The antisickling and antibacterial activities were assessed using Emmel and micro-dilution methods respectively. The results revealed that the leaves and stem bark of $U$. molundense contains various secondary metabolites such as total phenols, flavonoids, anthocyanins, tannins, quinones, saponins, alkaloids, steroids, terpenoids and leuco-anthocyanins. The n-hexane (non-polar solvent) extract displayed poor yield (0.66) than the extracts obtained in the polar solvents which have a high yield (Methanol: 1.68, Ethanol: 1.46 and Ethyl acetate: 1.40). These results indicate that the abundant secondary metabolites/compounds in this plant species are those which pass easily through the polar solvents (methanol, ethanol and ethyl acetate). This is the case of phytomarkers like flavonoids and tannins (which are most concentrated in methanol) and anthocyanins which are concentrated in ethyl acetate. The extraction yield of organic/triterpenoic acids (betulinic acid rich extract) was $1.70 \%$. All tested extracts displayed antisickling activity. At $100 \mu \mathrm{g} / \mathrm{mL}$, the rates of normalization were $89 \%$ for organic extract $(\mathrm{ED} 50=0.391 \mu \mathrm{g} / \mathrm{ml})$ and $82 \%$ for anthocyanins extract $(\mathrm{ED} 50$ $=0.659 \mu \mathrm{g} / \mathrm{mL}$ ). The antibacterial activity of tested extracts was very good toward Staphyloccocus areus (CMI $\leq 31.25 \mu \mathrm{g} / \mathrm{mL}$ ) while, for Escherichia coli, only the organic extract exhibit interesting activity $(\mathrm{CMI}=31.25 \mu \mathrm{g} / \mathrm{mL})$. This
\end{abstract}


study validates for the first time the in vitro antisickling activity of $U$. molundense. The bioactivity profiles of organic acids extract from the studied plant material indicate that they constitute promising fraction to be further investigated phytochemically for the discovery of new lead compounds for pharmaceutical application.

\section{Keywords}

Sickle Cell Disease, Traditional Foods, Nutraceuticals, Anthocyanins, Triterpenic Acids

\section{Introduction}

Sickle cell anemia (SCA) or Drepanocytosis is a genetic disease characterized by the presence of haemoglobin S in the blood [1] [2] [3] [4] [5]. All over the world, the number of individuals suffering from SCA is estimated at approximately 50 million of the people [6] and according to the World Health Organization (WHO), 300,000 children are born each year with a major anomaly from the hemoglobin of which most frequent is the SCA [7]. In Africa, SCA is the first genetic disease by the number of the patients [8]. In Democratic Republic of the Congo (DRC), $2 \%$ of the populations are sicklers and the majority of these patients die before the age of five years when they do not receive health care and those which survive however present an attack at the level of certain vital organs, which reduces considerably their life expectancy [9].

It was reported that in DRC, $12 \%$ of the children hospitalized in the hospital are sicklers and it is estimated that the annual cost of the treatment is higher than 1000 USD per patient [10], a cost hard to bear for the majority of the population whose average income is lower than 2 USD per day and who for the needs for primary health care turns mainly to traditional medicine and in particular the medicinal plants [11] [12] [13].

The plant species Uvariodendron molundense (Diels) R.E.Fr. belongs to the Annonaceae family. It leaves are consumed as traditional tea or used as spice by local communities of Nord Ubangi province in DRC and is effective against bacterial infections. The plant harvested in Cameroon was reported to possess antifungal, antioxidant and antiplasmodial activities [14] [15].

Recent findings revealed that the consumption of some tropical plants as foods by the non-human primates (great apes) protect them against hemolytic disease like malaria by inhibiting the Plasmodium falciparum inducing hemolysis of infected erythrocytes [16] [17]. Like for great apes, we hypothesized that the consumption of traditional foods/tea could also inhibit the erythrocytes hemolysis in human including those suffering from SCD. Indeed, great apes are reported as a good model for the understanding of eukaryotic cell hemolysis because they share with human a common gut anatomy [18] [19]. Thus, the traditional tea Uvariodendron molundense is expected to contain phytochemicals 
with anti-sickle cell anemia and antibacterial properties, which would act either individually, or in synergy. Indeed, the majority of the SCA children generally die by bacterial infections.

The aim of this study was to evaluate the chemical composition and bioactivity of $U$. molundense against Sickle cell disease and associated pathogenic bacteria agents in order to promote this dietary supplement as putative nutraceuticals. Indeed, patients with SCA usually suffer from intermittent clinical or hematologic crises. However, infection, and not crisis, is the most common cause of death, particularly in children. The antimicrobial resistance is therefore one of the most serious public health problems and constitutes one of the major causes of failure in the SCA infection treatment [16] [19]. Thus, direct or indirect antimicrobial effect $U$. molundense could warrant further studies as to the nature of active compounds and to determine the new strategy for prophylaxis in SCA infections.

\section{Materials and Methods}

\subsection{Plant Material Collection and Identification}

The tested plant material (leaves and bark) used in the present study was collected in Nord Ubangi Province (Democratic Republic of the Congo) during a field work in 2015 and was authenticated by Mr. Justin A. Asimonyio of the CSB (Centre de surveillance de la Biodiversité, University of Kisangani). Voucher specimen N0 JAA02NU is on deposit at the Laboratory of Molecular bio-prospection (Department of Biology, Faculty of Science, University of Kinshasa).

\subsection{Extraction, Chemical Screening and Preparation of Increasing Polarity Extracts}

The dried and powdered plant material $(10 \mathrm{~g})$ was repeatedly extracted by cold percolation with $95 \%$ ethanol $(\mathrm{EtOH})$ and water $(100 \mathrm{~mL} \times 2)$ for 48 hours.

Chemical screening was performed on the aqueous and organic extracts to investigate the presence of alkaloids, saponins, total polyphenols, flavonoids, tannins, anthocyanis, leuco-anthocyanins, quinones, terpenes and steroids according to standard protocol [20]. Fractions were filtered and concentrated to dryness under reduced pressure using a rotary evaporator. Organic/triterpenic acids were extracted as follow: the powdered material $(40 \mathrm{~g})$ were macerated with $100 \mathrm{~mL}$ of dichloromethane-methanol-NH4OH (100:1:1; v/v/v) and then percolated with $300 \mathrm{~mL}$ of the same solvent mixture at room temperature. The extract was concentrated under reduced pressure until $100 \mathrm{~mL}(\mathrm{pH} \mathrm{10)}$. The resulting solution was then mixed with $5 \%$ citric acid ( $v / v)$ to precipitate organic/triterpenic acids [21]. To obtain the increasing polarity extracts, the powdered plant material was exhaustively extracted with $n$-hexane (1:10, p/v), ethyl acetate, and methanol and acidified methanol ( $\mathrm{HCl} 1 \%)$. The resulting fractions were evaporated to dryness on an evaporator apparatus. All extracts were stored at $+4^{\circ} \mathrm{C}$. 


\subsection{Quantification of Secondary Metabolites}

\subsubsection{Total Phenolic}

Total phenolic contents were determined according to the Folin-Ciocalteu method with slight modifications [22]. The extract $(200 \mu \mathrm{L})$ was mixed with $1.5 \mathrm{~mL}$ of Folin-Ciocalteu reagent (previously diluted 10 times with double distilled water) and allowed to stand at room temperature for $5 \mathrm{~min} .1 .5 \mathrm{~mL}$ of sodium bicarbonate solution $(60 \mathrm{~g} / \mathrm{L})$ was added to the mixture and after incubation for 90 min at room temperature, the absorbance was measured at $725 \mathrm{~nm}$ using a UVVisible spectrophotometer (GENESYS 10S). Total phenolic were quantified by calibration curve obtained from measuring the absorbance of the known concentrations of gallic acid standard solutions (10 - $150 \mu \mathrm{g} / \mathrm{mL}$ in $80 \%$ methanol). The results were calculated as gallic acid equivalent (GAE) per one gram dry powder and reported as mean value \pm standard deviation (SD) (the standard curve equation: $\left.\mathrm{Y}=0.006 \mathrm{x}-0 . .002 ; \mathrm{R}^{2}=0.997\right)$.

\subsubsection{Flavonoids}

Total flavonoid content was measured by the aluminum chloride colorimetric method [23]. An aliquot $(1 \mathrm{~mL})$ of each extract was added to $10 \mathrm{~mL}$ volumetric flask containing $4 \mathrm{~mL}$ of double distilled water. Then $0.3 \mathrm{~mL} \mathrm{NaNO}{ }_{2} 5 \%$ was added to the flask and after $5 \mathrm{~min}, 0.3 \mathrm{~mL} \mathrm{AlCl}_{3}$ (10\%) was also added. At 6th min, $2 \mathrm{~mL} \mathrm{NaOH}(1 \mathrm{M})$ was added and the total volume was made up to $10 \mathrm{~mL}$ with double distilled water.

The solution was mixed completely and the absorbance was measured versus prepared reagent blank at $510 \mathrm{~nm}$. Total flavonoid content was expressed as $\mathrm{mg}$ quecertin equivalents $(\mathrm{QE})$ per one gram dry powder. One $\mathrm{mL}$ of standard solution (quecertin: $5-100 \mu \mathrm{g} / \mathrm{mL}$ ) was used to construct calibration curve (the standard curve equation: $\left.\mathrm{Y}=0.009 \mathrm{x}+0.006 ; \mathrm{R}^{2}=0.999\right)$.

\subsubsection{Anthocyanins}

The samples were diluted with the mixture ethanol/water/HCl conc. (70:30:1; $\mathrm{v} / \mathrm{v} / \mathrm{v}$ ) and the absorbance was measured at the wavelength of $540 \mathrm{~nm}$. The anthocyanins content (expressed as malvidin-3-glucoside equivalent, M-3-GE) was calculated using the following relation: Anthocyanins $=A_{540} *(10 / 0.6)^{*} \mathrm{~d}$ (with $\mathrm{A}_{540}=$ maximum of absorption at $540 \mathrm{~nm} ; \mathrm{d}=$ dilution factor; 0.6 maximum of absorption of $10 \mathrm{mg} / \mathrm{L}$ of M-3-GE standard solution) [24].

\subsubsection{Tannins}

To $1 \mathrm{ml}$ of the extract was added $7.5 \mathrm{ml}$ of distilled water and $0.5 \mathrm{ml}$ of FolinCiocalteu reagent and $1 \mathrm{ml}$ of sodium carbonate $\left(\mathrm{Na}_{2} \mathrm{CO}_{3} 35 \%\right)$. The absorbance was measured at the wavelength of $725 \mathrm{~nm}$. The tannins content (expressed as tannic acid equivalent, TAE) was calculated using the following relation: $\mathrm{Y}=$ $0.443 \mathrm{x}-0.264 ; \mathrm{R}^{2}=0.720[25]$.

\subsection{Biological Experiments}

\subsubsection{In Vitro Antisickling Bioassay}

Blood samples used to assess the antisickling activity of the selected plant ex- 
tracts were taken from known SCD patients attending the "Centre de Médecine Mixte et d'Anémie SS" located in Kinshasa, Democratic Republic of the Congo. None of the patients had been transfused recently with $\mathrm{Hb}$ AA blood and all antisickling experiments were carried out with freshly collected blood. In order to confirm their SS nature, the above-mentioned blood samples were first characterized by Hemoglobin electrophoresis on cellulose acetate gel to confirm their status and were then stored at $+4^{\circ} \mathrm{C}$ in a refrigerator. An informed consent was obtained from all the patients participating in the study and all the research procedures have received the approval of Department of Biology Ethics Committee.

An aliquot of $\mathrm{Hb}$ S-blood was diluted with $150 \mathrm{mM}$ phosphate buffered saline $\left(\mathrm{NaH}_{2} \mathrm{PO}_{4} 30 \mathrm{mM}, \mathrm{Na}_{2} \mathrm{HPO}_{4} 120 \mathrm{mM}, \mathrm{NaCl} 150 \mathrm{mM}\right)$ and mixed with an equivalent volume of $2 \%$ sodium metabisulfite. A drop from the mixture was spotted on a microscope slide in the presence or absence of plant extracts and covered with a cover slip.

Paraffin was applied to seal the edges of the cover completely to exclude air (Hypoxia). Duplicate analyses were run for each extract. The red blood cells (RBCs) were analyzed by a computer assisted image analysis software (Motic Images 2000, version 1.3; Motic China Group Co LTD) and statistical data analysis were processed using Microcal Origin 8.5 Pro package software as previously reported [26] [27] [28] [29] [30].

\subsubsection{Determination of Antibacterial Activity}

\section{- Microbial strains}

The activity of the plant samples was tested toward Staphylococcus aureus ( $S$. aureus ATCC 33591) and Escherichia coli (E. coli ATCC 27195) strains. The tested strains were obtained from the American Type Culture Collection (ATCC, Rockville MD, USA).

- Determination of Minimum inhibitory concentration (MIC)

The Minimum inhibitory concentration (MIC) was determined by broth micro-dilution method as reported in our previously research work [31] [32]. The inocula of used microorganisms were prepared from 24 hours old broth cultures. The absorbance was read at $600 \mathrm{~nm}$ and adjusted with sterile physiological solution $(0.9 \% \mathrm{NaCl})$ to match that of a $0.5 \mathrm{McFarland}$ standard solution $\left(10^{8}\right.$ cells $/ \mathrm{mL}$ ). The prepared microbial suspension was diluted (1/100) to achieve $10^{6}$ $\mathrm{CFU} / \mathrm{mL}$. Stock solutions of the plant extracts were prepared in Tween 80 (Fisher chemicals) $(3 \mathrm{mg} / 300 \mu \mathrm{L})$ and diluted to $2.7 \mathrm{ml}$ with Mueller Hinton Broth (MHB) (Conda, Madrid, Spain) to achieve a Tween 80 final concentration of $0.1 \%$. This solution was transferred in 96 -wells plates $(200 \mu \mathrm{L} /$ well $)$ and twofold serially diluted with $\mathrm{MHB}$ to give final concentrations ranging from 1000 to $3906 \mu \mathrm{g} / \mathrm{mL}$.

An aliquot $(10 \mu \mathrm{L})$ of $10^{6} \mathrm{CFU} / \mathrm{mL}$ overnight culture was added to wells of a sterile 96-well micro-plate titer. The positive control wells contained MHB+ bacteria suspension without plant extract while negative control wells contained MHB only. The MIC was determined as the lowest plant extract concentration at 
which no growth were observed after 24 hours. Resasurin $(30 \mu \mathrm{L})$ in aqueous solution $(0.01 \%)$ was used to evaluate the micro-organism viability.

Three independent experiments were run for the optimization of each in vitro bioassay.

\section{Results and Discussion}

\subsection{Phytochemical Study}

The chemical screening performed on the aqueous and alcoholic extracts of both leaves and bark of Uvariodendron molundense revealed the presence of alkaloids, saponins, total polyphenols, flavonoids, tannins, anthocyanis, leuco-anthocyanins, quinones, terpenes and steroids. Phenolic compounds such as anthocyanins [2] [3] [7] [8] [9] [11] [12] [13] [16] [26] [27] [28] [29] [30], rosmarinic acid [33] and lunularic acid [34] and triterpenes like betulinic, maslinic, oleanolic [35] and ursolic acid [36] were reported to display antisickling activity in vitro in our previous research works.

Table 1 gives the extraction yield and chemical composition of stem bark extracts from Uvariodendron molundense.

It is deduced from this table that the high yield (weight of the extract divided by weight of the plant powder multiplied by 100) was obtained with methanol following respectively by ethanol and ethyl acetate. However, n-hexane and acidified methanol displayed a poor yield. These results indicate that the abundant secondary metabolites/compounds in this plant species are those which pass easily through the polar solvents (methanol, ethanol and ethyl acetate).

This is the case of phytomarkers like flavonoids and tannins (which are most concentrated in methanol) and les anthocyanins which are concentrated in ethyl acetate. The presence of anthocyanins in all examined extracts suggests that they

Table 1. Extraction yield and chemical composition of leaves and bark of $U$. molundense (data from three independent experiments in triplicate).

\begin{tabular}{|c|c|c|c|c|c|}
\hline \multirow[b]{2}{*}{$\begin{array}{l}\text { Extract (used } \\
\text { part) }\end{array}$} & \multirow[b]{2}{*}{ Yield (\%) } & \multicolumn{4}{|c|}{ Secondary metabolites } \\
\hline & & $\begin{array}{l}\text { Total phenol } \\
(\mu \mathrm{g} \text { GAE/g) }\end{array}$ & $\begin{array}{l}\text { Flavonoids } \\
\text { ( } \mu \mathrm{g} \mathrm{QE} / \mathrm{g}) \\
\text { (\%ratio) }\end{array}$ & $\begin{array}{c}\text { Anthocyanins } \\
\text { ( } \mu \mathrm{g} \text { M-3-GE/g) } \\
\text { (\%ratio) }\end{array}$ & 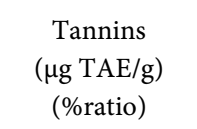 \\
\hline $\begin{array}{c}\text { n-hexane } \\
\text { (leaves) }\end{array}$ & 0.66 & $116.61 \pm 0.19$ & $1.96 \pm 0.17(1.7)$ & $1.11 \pm 0.03(0.9)$ & $0.93 \pm 0.01(0.8)$ \\
\hline $\begin{array}{c}\text { Ethyl acetate } \\
\text { (leaves) }\end{array}$ & 1.4 & $146.44 \pm 0.20$ & $2.66 \pm 0.48(1.8)$ & $2.57 \pm 0.03$ & $0.97 \pm 0.01(0.7)$ \\
\hline $\begin{array}{c}\text { Methanol } \\
\text { (leaves) }\end{array}$ & 1.68 & $93.44 \pm 0.10$ & $2.55 \pm 0.77(2.7)$ & $0.36 \pm 0.01(0.3)$ & $0.93 \pm 0.01(1.0)$ \\
\hline $\begin{array}{l}\text { Acidified } \\
\text { methanol } \\
\text { (leaves) }\end{array}$ & 0.7 & $148.33 \pm 0.44$ & $1.81 \pm 0.06(1.2)$ & $0.17 \pm 0.04(0.1)$ & $0.80 \pm 0.01(0.5)$ \\
\hline $\begin{array}{c}\text { Ethanol (stem } \\
\text { bark) }\end{array}$ & 1.46 & $174.39 \pm 0.10$ & $1.82 \pm 0.12(1.0)$ & $0.42 \pm 0.01(0.2)$ & $0.83 \pm 0.01(0.5)$ \\
\hline
\end{tabular}


could possess antisickling properties as reported elsewhere [2] [3] [7] [8] [9] [11] [12] [13] [16] [26] [27] [28] [29] [30]. The bioactive anthocyanins could be those which are acylated by organic acids [16]. In the present study, the extraction yield of organic/triterpenoic acids (betulinic acid rich extract) is $1.70 \%$. This value is greater than that of Uvariopsis congensis [19]. All of these extracts were tested for their antisickling and antibacterial effects.

\subsection{Antisickling Activity}

Figure 1 gives the morphology of untreated sickle erythrocytes and treated with Uvariodendron molundense extracts.

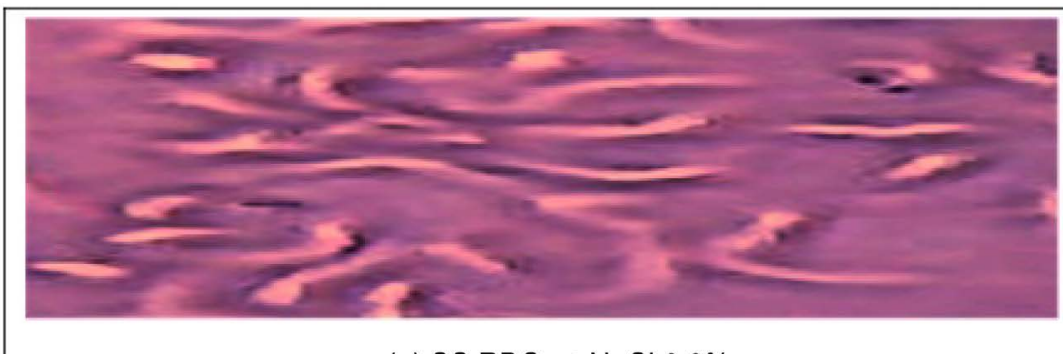

(a) SS RBCs $+\mathrm{NaCl} 0.9 \%$

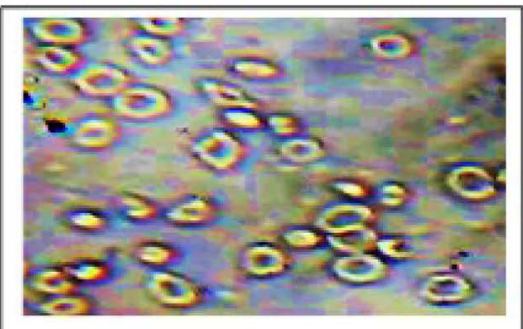

(c) SS RBCs + organic acids nichextract

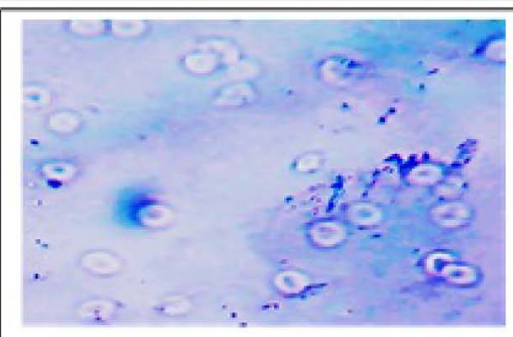

(b) SS RBCs + n-hexane extract

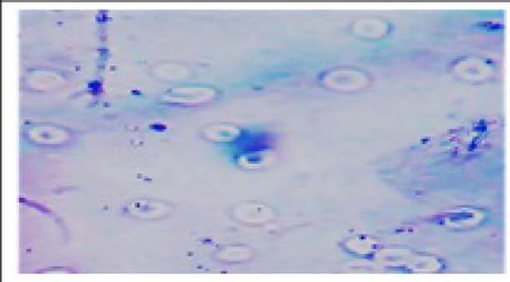

(d) SS RBCs + acidified MeOH extract

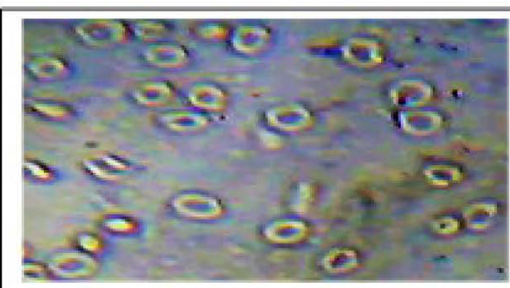

(e) SS RBCs + ethylacetate extract

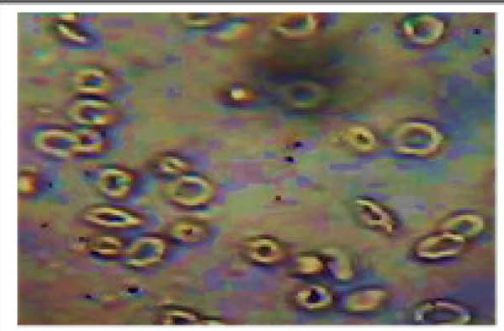

(f) SS RBCs + MeOH extract

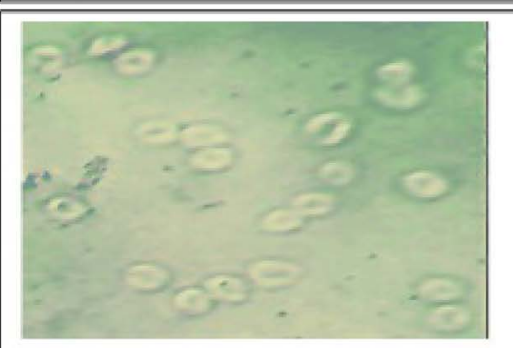

(g) SS RBCs + EtOH extract

Figure 1. Morphology of untreated sickle erythrocytes (a) or SS RBCs treated with $50 \mu \mathrm{g} / \mathrm{mL}$ of Uvariodendron molundense extracts (b)-(g) (X500), [ $\mathrm{NaCl} 0.9 \%$; $\left.\mathrm{Na}_{2} \mathrm{~S}_{2} \mathrm{O}_{5} 2 \%\right]$. 
Figure 1(a) reveals that the control sample contains in majority sickle-shaped erythrocytes, confirming the SS homozygous status of the used blood. Mixed together with different plant extracts (Figures $1(\mathrm{~b})-(\mathrm{g})$ ), the majority of erythrocytes are reversed normal-shape.

This indicates that Uvariodendron molundense have antisickling properties. The bioactivity displayed could be due to secondary metabolites like anthocyanins, phenolic or triterpenoic acids as previously reported [2] [3] [7] [8] [9] [11] [12] [13] [16] [26] [27] [28] [29] [30] [33] [34] [35] [36]. The morphology/ phenotype of treated sickle erythrocytes was remarkably similar to normal red blood cells (Figures 1(b)-(g)).

Figure 2 shows the dose dependent antisickling activity of both anthocyanins and triterpenic acids rich/organic acids extract from Uvariodendron molundense.

It can deduce from this figure that the normalization rate of sickled cells in hypoxic conditions increases with the extract concentration. At $100 \mu \mathrm{g} / \mathrm{mL}$, the rates of normalization were $89 \%$ for organic extract $\left(\mathrm{ED}_{50}\right.$ ie dose of extract for which $50 \%$ of the sickled erythrocytes are reversed equal to $0.391 \mu \mathrm{g} / \mathrm{ml}$ ) and $82 \%$ for anthocyanins extract $\left(\mathrm{ED}_{50}=0.659 \mu \mathrm{g} / \mathrm{mL}\right)$. Thus, the antisickling activity of the tested plant is dose dependent (Figure 2). It can be noticed also that the area under the curve was greater for organic acids extract than that of anthocyanins extract. This means that organic acids extract displays great bioactivity than anthocyanins extract one.

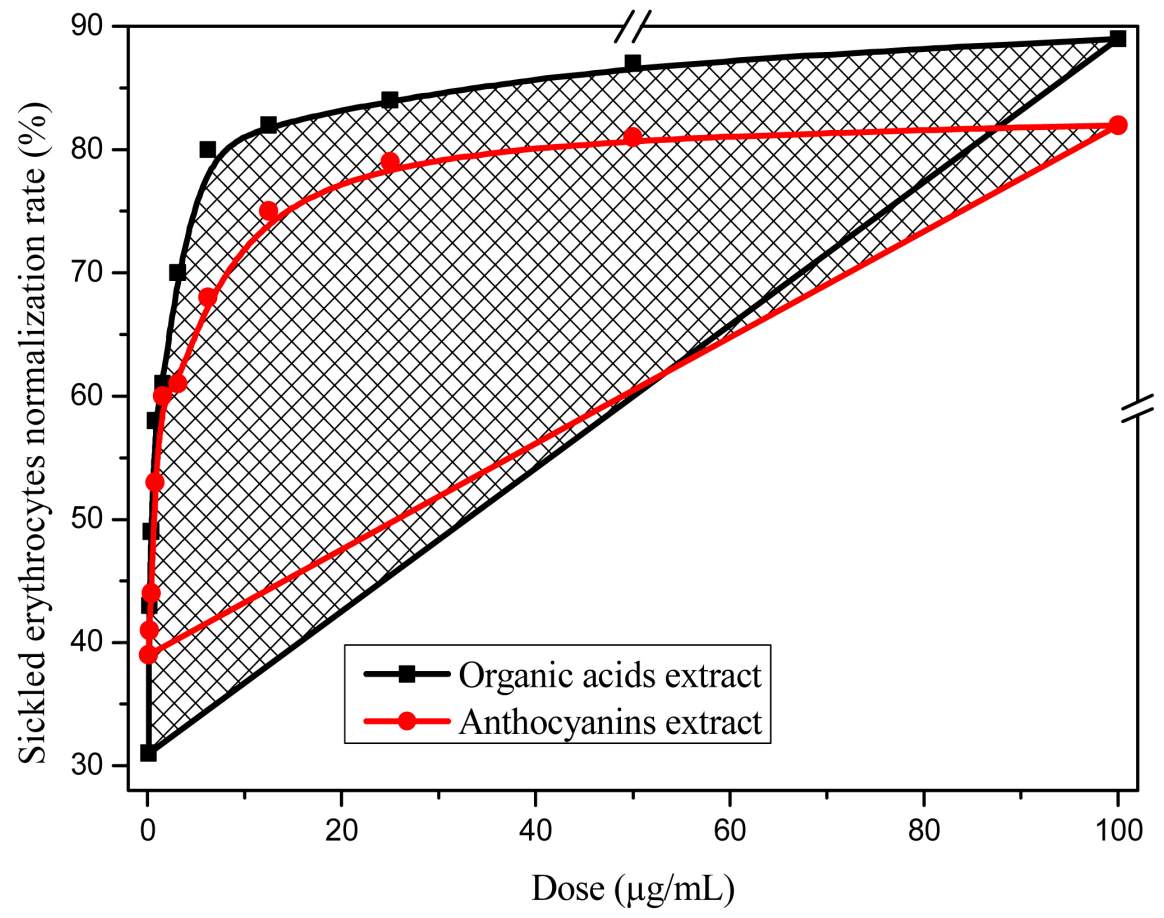

Figure 2. Dose-dependent normalization rate of sickled erythrocytes with bioactive compounds from Uvariodendron molundense $\left(\mathrm{NaCl} 0.9 \% ; \mathrm{Na}_{2} \mathrm{~S}_{2} \mathrm{O}_{5} 2 \%\right.$ ) (The curve was fitted with the help of Origin Pro 8.5 package software using B-spline: Fill Area Under the Curve and Inclusive broken by missing values). 
In this study, we demonstrated that all tested extracts are biologically active confirming the hypothesis that Uvariodendron molundense contains phytoconstituents which would act either individually, or in synergy, in order to confer him the antisickling properties. It is therefore suggested that bioactive extracts could exert their pharmacological effect by various mechanisms including the inhibition of free radicals formation, the inhibition of hemoglobin polymerization, and the inhibition of erythrocyte hemolysis as reported for others plants in our previous findings [18] [19]. Thus, oral supplementation of aqueous Uvariodendron molundense leaf extracts could abate oxidative stress, hemolysis and bacterial infections associated with clinical manifestation of SCA.

\subsection{Antibacterial Activity}

Due to the high cost of modern therapy for SCA, plant extracts displaying at the same time antibacterial and antisickling activities could be useful in the management of this hereditary blood disorder. The antibacterial activity of $U$ variodendron molundense extracts against $E$. coli and $S$. aureus two bacterial strains associated to this disease was evaluated and results are shown in Table 2.

It is deduced from this table that $S$. aureus is more sensitive to Uvariodendron molundense (all extracts have a CMI $\leq 31.25 \mu \mathrm{g} / \mathrm{mL}$ ) than $E$. coli (for which alone organic extract exhibit strong activity: $\mathrm{CMI}=31.25 \mu \mathrm{g} / \mathrm{mL}$ ). The difference in the bioactivity of tested extracts would be due to the nature of the bacterial wall structure [37] [38]. Indeed, contrary to $E$ coli, $S$. aureus is a positive gram bacterium.

Its wall is thick (several layers) and would constitute the pharmacological target of the biologically active compounds present in Uvariodendron molundense whereas for E coli, the external membrane would prevent some of secondary metabolites present in this medicinal plant species from penetrating in the bacterial cell. These results confirm the antimicrobial properties of the natural products of plant origin [31] [32]. It is well established that prokaryotic parasites like $S$. aureus and $E$ coli are the principal cause of septicemia and osteomyelitis

Table 2. Antibacterial activity (expressed as minimal inhibitory concentration, MIC) of Uvariodendron molundense extracts.

\begin{tabular}{ccc}
\hline & \multicolumn{2}{c}{ MIC $(\mu \mathrm{g} / \mathrm{mL})$} \\
\cline { 2 - 3 } Plant extracts (Used part) & E. coli ATCC 25922 & S. aureus ATCC 1103 \\
\hline n-hexane (leaves) & $500.00^{\mathrm{a}}$ & $31.250^{\mathrm{c}}$ \\
Ethyl acetate (leaves) & $500.00^{\mathrm{a}}$ & $31.250^{\mathrm{c}}$ \\
Methanol (leaves) & $1000^{\mathrm{b}}$ & $15.625^{\mathrm{d}}$ \\
Acidified methanol (leaves) & $500.00^{\mathrm{a}}$ & $31.250^{\mathrm{c}}$ \\
Organic acids (leaves) & $31.250^{\mathrm{c}}$ & $7.813^{\mathrm{e}}$ \\
Ethanol (bark) & $500.00^{\mathrm{a}}$ & $15.625^{\mathrm{d}}$ \\
\hline
\end{tabular}

Legend: ATCC: American Type Cell Collection. The values in the two last columns bearing different superscripts are significantly different $(\mathrm{p}<0.05),(\mathrm{n}=3$ independent experiments). 
in sickler patients [39]. So, plant extract displaying both antibacterial and antisickling properties is a suitable candidate for the development and standardization of medicine of pharmacological relevance for the management of SCA in endemic regions.

In the present research study, the bioactivity of organic acids extract is particularly interesting because of it inhibitory effect on $E$. coli $(\mathrm{CMI}=31.25 \mu \mathrm{g} / \mathrm{ml})$, a bacterial strain generally no sensitive to plant extracts [31] [32]. The isolation, purification and structure characterization of bioactive organic acids would be used as starting point for pharmaco-modulation, galenic formulation or models/precursors for a chemical synthesis on an industrial scale. To our knowledge, it is for the first time that the anti-sickle cell anemia properties of Uvariodendron molundense is reported in the literature. The leaves of this plant species is consumed as traditional tea or used as spice local communities of Nord Ubangi province. Consequently, dietary supplements with proven antisickling and bacterial inhibitory potentialities could be of great interest to promote for the management of SCD in this area as putative nutraceuticals.

\section{Conclusions and Suggestions}

The present study evaluated the chemical composition and the antisickling and antibacterial activities of Uvariodendron molundense. The results revealed that:

- The leaves and bark of $U$. molundense contain various secondary metabolites such as total phenols, anthocyanins, flavonoids, tannins, quinones, saponins, alkaloids, steroids, terpenoids and leuco-anthocyanins;

- All tested extracts displayed interesting antisickling activity. At $100 \mu \mathrm{g} / \mathrm{mL}$, the rates of normalization were $89 \%$ for organic extract $\left(\mathrm{ED}_{50}=0.391 \mu \mathrm{g} / \mathrm{ml}\right)$ and $82 \%$ for anthocyanins extract $\left(\mathrm{ED}_{50}=0.659 \mu \mathrm{g} / \mathrm{mL}\right)$.

- The antibacterial activity of the plant extracts was very good toward Staphyloccocus aureus (CMI $\leq 31.25 \mu \mathrm{g} / \mathrm{mL}$ ) while, for Escherichia coli, only the organic extract exhibit interesting activity (CMI $=31.25 \mu \mathrm{g} / \mathrm{mL})$.

This study provided experimental evidence that supports further development of $U$. molundense extracts as a medicine for the management of SCA in endemic areas. This plant species as dietary supplement with proven antisickling and bacterial inhibitory potentialities could be of great interest to promote for the management of SCA in this area as nutraceuticals. Further work is in progress to identify the compounds responsible for these interesting activities. It would be therefore necessary to evaluate the interaction of such phytochemicals with $\beta$ lactam based antibiotics against SCA pathogenic bacteria agents in order to increase the chances of success of prophylaxis with the combination of plant extracts/phytochemicals with oral penicillin as a suitable mean to prevent infections caused by such pathogens in children with SCA.

\section{Acknowledgements}

The authors are indebted to The World Academy of Sciences (TWAS) (Grant No. 15-156 RG/CHE/AF/AC_G-FR3240287018) for providing financial assistance. 


\section{References}

[1] Girot, R., Begué, P. and Galacteros, F. (2003) La drépanocytose. Editions John LIBBEY Eurotext, Paris, France.

[2] Ngbolua, K.N., Bishola, T.T., Mpiana, P.T., Mudogo, V., Tshibangu, D.S.T., Ngombe, K.N., Tshilanda, D.D. and Baholy, R. (2014) In Vitro Antisickling and Free Radical Scavenging Activities of Pentaclethra macrophylla Benth. (Fabaceae). Journal of Advancement in Medical and Life Sciences, 1, 1-6.

[3] Mpiana, P.T., Bokota, M.T., Ndjele, M.B.L., Mudogo, V., Tshibangu, D.S.T., Ngbolua, K.N., Atibu, E.K., Kwembe, J.T.K. and Makelele, L.K. (2010) Antisickling Activity of Three Species of Justicia from Kisangani (DR Congo): Justicia tenella, J. gendarusa and J. insularis. International Journal of Biological and Chemical Sciences, 4 , 1953-1961.

[4] Ngbolua, K.N., Bishola, T.T., Mpiana, P.T., Mudogo, V., Tshibangu, D.S.T., Ngombe, K.N., Ekutsu, E.G., Gbolo, B.Z. and Kabena, N.O. (2014) Ethno-Pharmacological Survey, in Vitro Antisickling and Free Radical Scavenging Activities of Carapa procera DC. Stem Bark (Meliaceae). Nova Journal of Medical and Biological Sciences, 2, 1-14. https://doi.org/10.20286/nova-jmbs-030130

[5] Yuma, P.M., Mpiana, P.T., Bokota, M.T., Wakenge, I.B., Muanishay, C.L., Gbolo, B.Z., Mathina Di Mathina, G., Tshibangu, D.S.T. and Ngbolua, K.N. (2013) Étude de l'activité antifalcemiante et de la thermo-et photo-dégradation des anthocyanes de Centella asiatica, Thomandersia hensii et Maesopsis eminii. International Journal of Biological and Chemical Sciences, 7, 1892-1901.

https://doi.org/10.4314/ijbcs.v7i5.9

[6] Mpiana, P.T., Tshibangu, D.S.T., Shetonde, O.M. and Ngbolua, K.N. (2007) In Vitro Antidrepanocytary Activity (Anti-Sickle Cell Anaemia) of Some Congolese Plants. Phytomedicine, 14, 192-195.

[7] Mpiana, P.T., Ngbolua, K.N., Mudogo, V., Tshibangu, D.S.T., Atibu, E.K., Tshilanda, D.D. and Misengabu, N.M. (2011) Anti Sickle Erythrocytes Haemolysis Properties and Inhibitory Effect of Anthocyanins Extracts of Trema orientalis (Ulmaceae) on the Aggregation of Human Deoxyhemoglobin S in Vitro. Journal of Medical Sciences, 11, 129-137. https://doi.org/10.3923/jms.2011.129.137

[8] Ngbolua, K.N., Mpiana, P.T., Tshibangu, D.S.T. and Gbolo, Z.B. (2015) Bioactivity of Medicinal Plants Traditionally Used for the Management of Sickle Cell Disease in Democratic Republic of the Congo: State of the Art and Future Directions. Sickle Cell Disease: Genetics, Management and Prognosis, NOVA Publishers, New York, 79-94.

[9] Ngbolua, K.N. and Mpiana, P.T. (2014) The Possible Role of a Congolese Polyherbal Formula (Drepanoalpha') as Source of Epigenetic Modulators in Sickle Cell Disease: A Hypothesis. Journal of Advancement in Medical and Life Sciences, 2.

[10] Tshilolo, L., Aissi, L.M., Lukusa, D., Kinsiama, C., Wembonyama, S., Gulbis, B. and Vertongen, F. (2009) Neonatal Screening for Sickle Cell Anaemia in the Democratic Republic of Congo: Experience from a Pioneer Project on 31204 Newborns. Journal of Clinical Pathology, 62, 35-38. https://www.ncbi.nlm.nih.gov/pubmed/19103857 https://doi.org/10.1136/jcp.2008.058958

[11] Mpiana, P.T., Ngbolua, K.N, Bokota, M.T., Kasonga, T.K., Atibu, E.K. and Mudogo, V. (2010) In Vitro Effects of Anthocyanins Extracts from Justicia secunda Vahl on the Solubility of Hemoglobin S and Membrane Stability of Sickle Erythrocytes. Blood Transfusion, 8, 248-254. https://www.ncbi.nlm.nih.gov/pmc/articles/PMC2957489/

[12] Ngbolua, K.N., Mudogo, V., Mpiana, P.T., Malekani, M.J., Rafatro, H., Urverg 
Ratsimamanga, S., Takoy, L., Rakotoarimana, H. and Tshibangu, D.S.T. (2013) Evaluation de l'activité anti-drépanocytaire et antipaludique de quelques taxons végétaux de la République démocratique du Congo et de Madagascar. Ethnopharmacologia, 50, 19-24.

[13] Ngbolua, K.N., Shetonde, O.M., Mpiana, P.T., Inkoto, L.C., Masengo, C.A., Tshibangu, D.S.T., Gbolo, B.Z., Robijaona, B. and Fatiany, P.R. (2016) Ethno-Pharmacological Survey and Ecological Studies of Some Plants Used in Traditional Medicine in Kinshasa City (Democratic Republic of the Congo). Tropical Plant Research, 3, 413-427.

[14] Menkem, E.Z., Fokou, J.-B.H., Tsague, I.F.K., Chouadeu, P.M., Bakarnga-Via, I., Kamdem, M.S., Nya, P.B., Fokou, V.P.T., Mofor, C.T. and Boyom, F.F. (2013) Antifungal and Antioxidant Activities of Piptostigma calophyllum, Uvariodendron calophyllum and Uvariodendron molundense Growing in Cameroon. Journal of Biologically Active Products from Nature, 2, 110-118.

[15] Boyoma, F.F., Fokoua, P.V.T., Tchokouaha, L.R.Y., Mfopaa, A.N., Kemgnea, E.M., Mbachamb, W.F., Tsamoc, E., Zolloa, P.H.A., Gutd, J. and Philip, J.R. (2011) Potent Antiplasmodial Extracts from Cameroonian Annonaceae. Journal of Ethnopharmacology, 134, 717-724.

[16] Ngbolua, K.N. (2012) Evaluation de l'activité anti-drépanocytaire et antipaludique de quelques taxons végétaux de la République Démocratique du Congo et de Madagascar. Thèse de Doctorat, Université de Kinshasa, République Démocratique du Congo.

[17] Krief, S., Escalante, A.A., Pacheca, M.A., Mugisha, L. and André, C. (2010) On the Diversity of Malaria Parasites in African Apes and the Origin of P. falciparum from Bonobos. PLoS Pathogens, 6, e1000765.

https://www.ncbi.nlm.nih.gov/pmc/articles/PMC2820532/ https://doi.org/10.1371/journal.ppat.1000765

[18] Tshibangu, D.S.T., Ngbolua, K.N., Lengbiye, E.M., Tshilanda, D.D., Mvingu, B.M., Iteku, B.J., Mbala, B.M., Mudogo, V. and Mpiana, P.T. (2016) Chemical Composition and Bioactivity of Canarium schweinfurthii Stem Bark Extracts from DR Congo against Sickle Cell Disease and Associated Bacteria. Journal of Pharmacognosy and Phytochemistry, 5, 181-187.

[19] Ngbolua, K.N., Lengbiye, E.M., Masengo, C.A., Asimonyio, J.A., Kambale, J.L.K., Tshibangu, D.S.T., Ngombe, N.K., Kamika, I. and Mpiana. P.T. (2016) Antisickling and Antibacterial Activities of Uvariopsis congensis. Discovery Phytomedicine, 3, 7-14. https://doi.org/10.15562/phytomedicine.2016.33

[20] Bruneton, J. (1999) Pharmacognosie, Phytochimie des Plantes Médicinales. 3rd Edition, Revue et Augmentée, Tec \& Doc, Paris.

[21] Pezzuto, J.M. and Kim Darrick, S.H.L. (1999) Improved Methods of Manufacturing Betulinic Acid. US Patent No. 5804575, US Patent and Trademark Office, Washington DC.

[22] Gutfinger, T. (1981) Polyphenols in Olive Oils. Journal of the American Oil Chemists Society, 58, 966-968. https://doi.org/10.1007/BF02659771

[23] Querttier-Deleu, C., Gressier, B., Vassseur, J., Dine, T., Brunet, C., Luyckx, M.C., Cazin, J.C., Bailleu, F. and Trotin, F. (2000) Phenolic Compounds and Antioxidant Activities of Buckwheat (Fagopyrum esculentum Moench) Hulls and Flour. Journal of Ethnopharmacology, 72, 35-42. https://www.ncbi.nlm.nih.gov/pubmed/10967451

[24] Di Stefano, R., Cravero, M.C. and Gentilini, N. (1989) Meto-di per lo studio dei polifenoli dei vini. L'enotecnico, 5, 83-90.

[25] Makkar, H.P.S., Bluemmel, M., Borowi, N.K. and Beker, K. (1993) Gravimetric De- 
termination of Tannins and Their Correlations with Chemical and Protein Precipitation Methods. Journal of the Science of Food and Agriculture, 61, 161-165. https://doi.org/10.1002/jsfa.2740610205

[26] Mpiana, P.T., Mudogo, V., Nyamangombe, L., Kakule, M.K., Ngbolua, K.N., Atibu, E.K., Mbala, M.B., Mbongo, A.K. and Ntumba, J.N. (2009) Antisickling Activity and Photodegradation Effect of Anthocyanins Extracts from Alchornea cordifolia (Schumach \& Thonn.) and Crotalaria retusa L. Annals of African Medicine, 2, 240245.

[27] Mpiana, P.T., Misakabu, F.M., Kitadi, J.M., Ngbolua, K.N., Tshibangu, D.S.T., Lombe, B.K., Tsalu, P.V., Atibu, E.K., Gbolo, B.Z. and Muanishay, C.L. (2014) Antisickling Activity and Physico-Chemical Stability of Anthocyanin Extracts from Hypoxis angustifolia Lam. (Hypoxidaceae) Bulbs. In: Noboru, M., Ed., Anthocyanins. Occurrence, Structure, Biosynthesis and Health benefits Based on their Evidences of Phytochemicals in Vegetables and Fruits, Vol. 2, NOVA Science Publishers, Inc., New York, 97-113.

[28] Mpiana, P.T., Mudogo, V., Tshibangu, D.S.T., Ngbolua, K.N., Atibu, E.K., Kitwa, E.K., Kanangila, A.B. and Makelele, L.K. (2009) Activité antifalcémiante et thermodégradation d'une fraction d'anthocyanes extraits de Zizyphus mucronata. Annals of African Medicine, 2, 91-97.

[29] Mpiana, P.T., Mudogo, V., Tshibangu, D.S.T., Shetonde, O.M., Ngbolua, K.N. and Mbala, M.B. (2007) Antisickling Activity of Some Congolese Plants. In: Drug Discovery from African Flora, The 12 th Symposium of the Natural Product Research Network for Eastern and Central Africa, 22-26 July 2007, University of Makerere, Kampala, Uganda, 45 (PS-6).

[30] Mpiana, P.T., Mudogo, V., Tshibangu, D.S.T., Ngbolua, K.N., Mangwala, P.K., Atibu, E.K., Kakule, M.K., Makelele, L.K. and Bokota, M.T. (2010) Antisickling Activity and Thermodegradation of an Anthocyanin fraction from Ocimum basilicum L. (Lamiaceae). In: Gupta, V.K., Ed., Complementary and Bioactive Natural Products, Vol. 3. Effects, Safety \& Clinical (Pt II), Studium Press LLC, USA, 278-287.

[31] Ngbolua, K.N., Mubindukila, N.R., Mpiana, P.T., Masengo, C.A., Baholy, R., Fatiany, P.R., Ekutsu, G.E. and Gbolo, B.Z. (2014) In Vitro Assessment of Antibacterial and Antioxidant Activities of a Congolese Medicinal Plant Species Anthocleista schweinfurthii Gilg (Gentianaceae). Journal of Modern Drug Discovery and Drug Delivery Research, 1, 1-6.

[32] Ngbolua, K.N., Mubindukila, N.R., Mpiana, P.T., Tshibangu, D.S.T., Masengo, C.A., Nzongola, K., Baholy, R. and Fatiany, P.R. (2014) Phytochemical Screening, Antibacterial and Antioxidant Activities of Anthocleista liebrechtsiana Wild \& T. Durand (Gentianaceae) Originated from Democratic Republic of the Congo. Journal of Advancement in Medical and Life Sciences, 1, 1-6.

[33] Tshilanda, D.D., Onyamboko, D.V.N., Babady, P.B., Mutwale, P.K., Tsalu, P.V., Tshibangu, D.S.T., Ngombe, N.K., Ngbolua, K.N. and Mpiana, P.T. (2016) Chemical Fingerprint and Anti-Sickling Activity of Rosmarinic Acid and Methanolic Extracts from Three Species of Ocimum from DR Congo. Journal of Biosciences and Medicines, 4, 59-68. https://doi.org/10.4236/jbm.2016.41008

[34] Ngbolua, K.N., Rafatro, H., Rakotoarimanana, H., Mudogo, V., Mpiana, P.T., Tshibangu, D.S.T. and Tshilanda, D.D. (2015) In Vitro Anti-Erythrocyte Sickling Effect of Lunularic Acid of Natural Origin. International Blood Research \& Reviews, 4, 1-6. https://doi.org/10.9734/IBRR/2015/21718

[35] Tshibangu, D.S.T., Shode, F.O., Koorbanally, N., Mudogo, V., Mpiana, P.T. and Ngbolua, K.N. (2011) Antisickling Triterpenoids from Callistemon viminalis, Meulaleuca bracteata var. Revolution Gold, Syzygium guineense and Syzygium corda- 
tum. The 14th NAPRECA Symposium and AAMPS Ethnoverterinary Medicine Symposium, 8-12 August 2011, International Centre for Insect Physiology and Ecology (ICIPE), Kasarani, Nairobi, Kenya, 296-300 (YS 27).

[36] Tshilanda, D.D., Onyamboko, D.N.V., Babady, P.B., Ngbolua, K.N., Tshibangu, D.S.T., Dibwe, E.F. and Mpiana, P.T. (2015) Anti-Sickling Activity of Ursolic Acid Isolated from the Leaves of Ocimum gratissimum L. (Lamiaceae). Natural Products and Bioprospecting, 5, 215-221. https://doi.org/10.1007/s13659-015-0070-6

[37] Ngbolua, K.N., Tshibangu, D.S.T., Mpiana, P.T., Shetonde, O.M., Mavakala, B.K., Masengo, A.C. and Muanyishay, L.C. (2015) Anti-Sickling and Antibacterial Activities of Some Extracts from Gardenia ternifolia subsp. jovis-tonantis (Welw.) Verdc. (Rubiaceae) and Uapaca heudelotii Baill. (Phyllanthaceae). Journal of Advances in Medical and Pharmaceutical Sciences, 2, 10-19. https://doi.org/10.9734/JAMPS/2015/13427

[38] Ngbolua, K.N., Mpiana, P.T., Akoundze, J.B., Mwanza, F.B., Tshibangu, D.S.T., Masengo, C.A., Liesse, L. and Takaisi, K. (2016) Anti-Sickling and Bacterial Inhibitory Effects of Two Medicinal Foods from the Congo River Basin: Gnetum africanum Welw. (Gnetaceae) and Grewia coriacea Mast. (Malvaceae). Current Traditional Medicine, 2, 34-41.

[39] Diagne, I., Diagne-Gueye, N.D., Signate-Sy, H., Camara, B., Lopez-Sall, P., DiackMbaye, A., Sarr, M., Ba, M., Sow, H.D. and Kuakuvi, N. (2003) Management of Children with Sickle Cell Disease in Africa: Experience in a Cohort of Children at the Royal Albert Hospital in Dakar. Médecine Tropicale, 63, 513-520.

Submit or recommend next manuscript to SCIRP and we will provide best service for you:

Accepting pre-submission inquiries through Email, Facebook, LinkedIn, Twitter, etc. A wide selection of journals (inclusive of 9 subjects, more than 200 journals)

Providing 24-hour high-quality service

User-friendly online submission system

Fair and swift peer-review system

Efficient typesetting and proofreading procedure

Display of the result of downloads and visits, as well as the number of cited articles

Maximum dissemination of your research work

Submit your manuscript at: http://papersubmission.scirp.org/

Or contact jbm@scirp.org 